\title{
The surface physicochemistry and adhesiveness of Shewanella are affected by their surface polysaccharides
}

Correspondence

Anton Korenevsky

aak@uoguelph.ca

Received 27 October 2006

Revised 12 February 2007

Accepted 13 February 2007

\author{
Anton Korenevsky and Terry J. Beveridge
}

Department of Molecular and Cellular Biology and Advanced Foods and Materials Network -
Networks of Centres of Excellence, University of Guelph, Guelph, Ontario N1G 2W1, Canada

Shewanella strains have previously been studied with regard to their cell surface ultrastructure and LPS composition. They have now been further characterized with respect to their surface physicochemistry and ability to adhere to haematite. The surfaces of the Shewanella strains were found to be electronegative and hydrophilic, and these properties could be correlated with LPS composition or the presence of capsular polysaccharides. Strains expressing rough LPS with no capsule were more hydrophobic and electronegative than those possessing smooth LPS or capsules. By combining different approaches, such as contact-angle measurement, hydrophilic/ hydrophobic chromatography, microelectrophoresis, adhesion assays and calculation of interaction energies, it was shown that electrostatic interactions predominate over hydrophobic interactions at the cell-iron oxide interface. Bacterial adhesion to haematite was significantly reduced in strains expressing smooth LPS or a capsule. These findings remained true for Shewanella strains grown under either aerobic or anaerobic conditions, although the surfaces of anaerobic cells appeared to be less electronegative and more hydrophilic than those of aerobic cells.

\section{INTRODUCTION}

Dissimilatory iron-reducing bacteria (DIRB), such as Shewanella, play important roles in the geochemical cycling of iron oxides and associated metal/organic contaminants in anaerobic sedimentary subsurface environments (Thamdrup, 2000; Lovley et al., 2004). Ferric iron, the most abundant electron acceptor in non-sulfidogenic environments, occurs in sediments as particulate (hydro)oxides of various crystallinity (Thamdrup, 2000). To reduce iron oxides at circumneutral $\mathrm{pH}$, Gram-negative DIRB generate respiratory chain components, e.g. $c$-type cytochromes, in their outer membrane $(\mathrm{OM})$ and periplasm (Myers \& Myers, 1992; Gaspard et al., 1998; Beliaev et al., 2001; Ruebush et al., 2006). The OM cytochromes are iron reductases capable of transferring electrons directly to $\mathrm{Fe}(\mathrm{III})$ in the mineral crystal lattice (Gaspard et al., 1998; Myers \& Myers, 2004; Mehta et al., 2005; Ruebush et al., 2006), although other proteins may also play important roles in electron transport (Reguera et al.,

Abbreviations: AFM, atomic force microscopy; DIRB, dissimilatory ironreducing bacteria; DLVO, Derjaguin, Landau, Verwey and Overbeek; ESIC, electrostatic interaction chromatography; HIC, hydrophobic interaction chromatography; LW, Lifshitz-van der Waals; OM, outer membrane; OMP, outer-membrane protein; PS, polysaccharide; RSC, relative surface charge; $\mathrm{RSH}$, relative surface hydrophobicity; TEM, transmission electron microscopy.
2005). Direct contact is required between Shewanella and the metal-oxide surface to ensure effective electron transfer (Arnold et al., 1988; Myers \& Nealson, 1988; Caccavo et al., 1996; Grantham et al., 1997; Das \& Caccavo, 2000); however, cell adhesion to minerals is not necessary when soluble electron shuttles or iron-complexing agents are produced (Arnold et al., 1988; Lovley \& Woodward, 1996; Lovley et al., 1998; Newman \& Kolter, 2000; Nevin \& Lovley, 2002; Turick et al., 2002).

Contact between DIRB and iron oxide may occur through reversible or irreversible adhesion. According to the Derjaguin, Landau, Verwey and Overbeek (DLVO) theory, the outcome is determined by the physicochemical properties of both bacterial and mineral surfaces, and is a result of the interplay of long-range electrostatic and van der Waals forces. However, bacterial adhesion is also characterized by non-DLVO interactions such as those derived from steric and Lewis acid-base interactions. These are short-range forces and are responsible for such interfacial effects as hydrophobic attraction and hydrophilic repulsion (Van Oss, 1994). Together, these long- and short-range interactions control the distance between the bacterium and the mineral interface, and hence, electron transfer to the iron oxide. It is important to determine which forces are operational during adhesion and which surface macromolecules contribute, so as to understand the bioreduction of iron oxides. 
Shewanella readily adhere to iron oxides, preferring these to other minerals (Caccavo et al., 1997; Grantham et al., 1997; Glasauer et al., 2001; Lower et al., 2001). The exact mechanism of adhesion is not completely understood. Transmission electron microscopy (TEM), atomic force microscopy (AFM) and differential centrifugation have revealed strong associations between the bacteria and iron oxides, implying that the adhesion may be irreversible (Glasauer et al., 2001; Lower et al., 2001). Yet, during anaerobic pitting of iron oxide-coated quartz, cells remain passively mobile on the mineral surfaces, moving from one region to another (Grantham et al., 1997). Shewanella therefore appear to be able to formulate adhesive forces for strong contact, and yet, break these forces so as to systematically migrate across mineral surfaces. To complicate matters further, it has been suggested that electrostatic interactions govern this adhesion (Grantham et al., 1997), but other studies suggest that the initial attachment of Shewanella algae is dominated by hydrophobic interactions mediated by surface proteins (Caccavo et al., 1997; Caccavo, 1999).

Clearly, processes at the cell-mineral interface are complex and dynamic and go beyond mere single-site adhesion, being governed by a range of transient physicochemical interactions. These interactions can be mediated by a variety of surface components, such as outer-membrane proteins (OMPs) or LPSs, ultimately controlled by cell sensors and physiological processes, so that adhesion can be initiated or broken by the cell (Vadillo-Rodríguez et al., 2004b). Given that LPS $O$ side chains can extend considerable distances from the cell surface, that LPS can possess more exposed electrostatic sites than does protein and that LPS is the most abundant macromolecule on the Gram-negative surface (Beveridge, 1999), LPS is a major candidate for interaction with mineral surfaces.

Recently, we have characterized different Shewanella spp. with respect to LPS composition and surface structure (Korenevsky et al., 2002; Vinogradov et al., 2002, 2003a, b, 2004, 2005). Many express rough LPS only (i.e. LPS possessing core oligosaccharide and no $O$ side chain); however, approximately one-half produce smooth LPS or capsular polysaccharide (PS). Thin sections of freezesubstituted cells have revealed that strains of Shewanella oneidensis and $S$. algae possess either $O$ side chains or capsules extending 20-130 $\mathrm{nm}$ from the cell (Korenevsky et al., 2002). In this current work, we determined how the composition and length of surface PS polymers influence surface properties such as hydrophobicity and surface charge, and in turn, how these properties affect the ability to adhere to haematite.

\section{METHODS}

Bacterial strains and growth conditions. We used those strains that have previously been characterized with respect to surface ultrastructure and LPS composition (Korenevsky et al., 2002): Shewanella putrefaciens CN32, S. oneidensis MR-1, S. oneidensis MR-4, Shewanella baltica 63 and S. algae BrY. During our study, strains such as BrY and MR-4 readily converted from encapsulated to rough LPS phenotypes when grown under identical conditions. The basis for this was not investigated, but it did provide a good opportunity to study the physicochemistry of the variants, which appeared identical in all other phenotypic traits. These encapsulated $\left(\mathrm{BrY}^{\mathrm{FCs}}\right)$ and rough $\left(\mathrm{BrY}^{\mathrm{DLr}}\right.$ and MR-4r) variants were selected on the basis of colony appearance on trypticase soy agar (TSA). These variants appeared to be fairly stable, since they retained their phenotype during serial passaging on solidified (TSA) or liquid [trypticase soy broth (TSB) or chemically defined medium (CDM)] media. All cultures were grown in TSB on a rotary shaker ( 150 r.p.m.) at $24^{\circ} \mathrm{C}$, or anaerobically in serum bottles in CDM, as described by Fredrickson et al. (1998), containing $7.57 \mathrm{mM}$ $\left(\mathrm{NH}_{4}\right)_{2} \mathrm{SO}_{4}, 3.43 \mathrm{mM} \mathrm{K} \mathrm{KPO}_{4}, 0.37 \mathrm{mM} \mathrm{MgCl} .6 \mathrm{H}_{2} \mathrm{O}, 0.34 \mathrm{mM}$ $\mathrm{CaCl}_{2} \cdot 2 \mathrm{H}_{2} \mathrm{O}, 1.36 \mathrm{mM}$ L-glutamic acid, $4.2 \mathrm{mM}$ HEPES, $20 \mathrm{mM}$ sodium lactate (as an electron donor), and $40 \mathrm{mM}$ sodium fumarate or $30 \mathrm{mM}$ ferric citrate (as an electron acceptor). The headspace atmosphere was $100 \% \mathrm{~N}_{2}$ and $\mathrm{pH}$ was adjusted to 6.8 with $\mathrm{NaOH}$.

Cells were harvested at mid- to late-exponential growth phase by centrifugation at $5000 \mathrm{~g}$ for $15 \mathrm{~min}$, and then washed twice in $0.1 \mathrm{M}$ $\mathrm{NaCl} / 0.05 \mathrm{M}$ HEPES buffer ( $\mathrm{pH}$ 7.4) to remove residual medium. In the case of anaerobically grown cells, washing was performed with anaerobic buffer after sparging with $\mathrm{N}_{2}$. The handling of anaerobically grown cells was carried out in a glove box under an argon atmosphere.

Iron oxides. The adhesion experiments required a well-defined iron oxide surface with a relatively large particle size $(>1 \mu \mathrm{m})$. The most common iron minerals in the subsurface, such as hydrous ferric oxide (HFO) or green rust, are highly dispersed and poorly crystalline, and would not be suitable. Since surface physicochemical parameters such as surface charge and wettability, which are important and affect adhesion, are not highly variable among different ferric oxides (Kosmulski, 2001, 2006; Giese \& Van Oss, 2002), haematite (>99.0\%; Fluka, catalogue no. 44954) was used as a stable iron oxide for our adhesion experiments. X-ray powder spectra revealed X-ray diffraction (XRD) patterns corresponding to single-phase $\alpha-\mathrm{Fe}_{2} \mathrm{O}_{3}$ (haematite).

The haematite was washed 10 times with deionized water, all the while decanting off the fine particles and collecting the coarser sediment fraction. The sediment was then dried at $60^{\circ} \mathrm{C}$. A haematite particle size of $2.84 \pm 1.34 \mu \mathrm{m}$ was determined by measuring 120 particles using a Nanoscope Dimension 3100 atomic microscope operating in the tapping mode. The error in particle horizontal dimensions associated with tip convolution effect was assessed by comparing the particle profiles acquired in the trace and retrace directions. The error in the AFM measurements was found to be $<6 \%$. High resolution acid-base titration (QC-Titrate; Man-Tech Associates) showed that the haematite had a point of zero charge (PZC) of $8.51 \pm 0.06$.

Relative cell-surface hydrophobicity measured by hydrophobic interaction chromatography (HIC). HIC was carried out as described by MacDonald \& Beveridge (2002). Two sets of Bio-Rad Econo columns were used in the assay. One set was packed with $2 \mathrm{ml}$ Octyl-Sepharose CL-4B beads (Sigma-Aldrich), and the other with $2 \mathrm{ml}$ Sepharose CL-4B beads (control columns). The column beads were rinsed three times with $4 \mathrm{ml}$ Nanopure water and four times with $4 \mathrm{ml}$ appropriate saline solution $[0.1,1.0,2.0,3.0$ and $4.0 \mathrm{M}$ $\mathrm{NaCl}$ buffered with $10 \mathrm{mM}$ potassium phosphate buffer (PB), $\mathrm{pH}$ 7.4]. Bacterial cells were harvested by centrifugation and washed with $0.1 \mathrm{M} \mathrm{NaCl} / \mathrm{PB}$. The pellet was resuspended in $50 \mathrm{ml} 0.1 \mathrm{M}$ $\mathrm{NaCl} / \mathrm{PB}$ to obtain $\mathrm{OD}_{470} 0.6$. The suspension was centrifuged and resuspended in $5 \mathrm{ml} 0.1 \mathrm{M} \mathrm{NaCl} / \mathrm{PB}$. Aliquots $(1 \mathrm{ml})$ of this cell suspension were placed in five separate Eppendorf tubes and spun at $5000 \mathrm{~g}$ for $5 \mathrm{~min}$. Each pellet was resuspended in $400 \mu \mathrm{l}$ of the 
appropriate buffered saline solution (0.1-4.0 M NaCl). Aliquots of $200 \mu \mathrm{l}$ were added to appropriate hydrophobic and control columns, left for $15 \mathrm{~min}$ for equilibration, and then washed with $4 \mathrm{ml}$ of the appropriate buffered saline solution. The eluate was collected and its $\mathrm{OD}_{470}$ measured. Relative surface hydrophobicity (RSH) was expressed as the percentage retained by Octyl-Sepharose relative to the more hydrophilic control column, at each saline concentration. Cell retention by the control column (Sepharose CL-4B) was found to be in the range $0-13 \%$.

Relative cell surface electronegativity measured by electrostatic interaction chromatography (ESIC). ESIC was performed in a similar manner to HIC, except that the columns were packed with DEAE-Sepharose CL-6B and Sepharose CL-6B (Sigma-Aldrich). Column rinsing and cell equilibration/elution were performed with potassium phosphate buffer at concentrations of $0.05,0.1,0.15,0.2$, 0.4 and $0.6 \mathrm{M}$ at $\mathrm{pH}$ 7.4. Relative surface charge (RSC) was expressed as the percentage retained by DEAE-Sepharose relative to the neutrally charged control column, at each saline concentration. Cell retention by the control column (Sepharose CL-6B) was found to be in the range $0-18 \%$.

Zeta potentials. Zeta potential $(\zeta)$ is defined as the electric potential at the plane of hydrodynamic shear. A Doppler electrophoretic lightscattering analyser (Zetasizer Nano ZS; Malvern Instruments) was used to measure the electrophoretic mobility, with conversion to zeta potential using Smoluchowski's approximation. Measurements were performed with cells suspended either in $0.1 \mathrm{M} \mathrm{NaCl} / 0.05 \mathrm{M}$ HEPES or in $0.01 \mathrm{M} \mathrm{NaCl}$, both at $\mathrm{pH} 7.4$, after adjustment with $0.01 \mathrm{M}$ $\mathrm{NaOH}$ or $0.01 \mathrm{M} \mathrm{HCl}$.

Calculation of interaction energies. Surface free energies of interaction between haematite and cells were determined using the approach proposed by van Oss and co-workers (Van Oss et al., 1986; Van Oss, 1994). Total surface tension $\left(\gamma^{\text {TOT }}\right)$ is calculated as a sum of the apolar $\left(\gamma^{\mathrm{LW}}\right)$ and polar $\left(\gamma^{\mathrm{AB}}\right)$ components:

$\gamma^{\mathrm{TOT}}=\gamma^{\mathrm{LW}}+\gamma^{\mathrm{AB}}$

The apolar component reflects Lifshitz-van der Waals (LW) attractive interactions and the polar component reflects Lewis acid-base (AB) interactions, which account for such effects as hydrophobic attraction and hydrophilic repulsion. Furthermore, the polar (AB) properties of a surface are described by two parameters, namely the electron acceptor parameter $\gamma^{+}$and the electron donor parameter $\gamma^{-}$:

$\gamma^{\mathrm{AB}}=2\left(\gamma^{+} \cdot \gamma^{-}\right)^{1 / 2}$

For a given solid (S), the surface-tension components can be obtained by means of contact angle $(\theta)$ measurements using at least three separate liquids (L) as probes, one being apolar and the other two polar, and all with known surface-tension components. Then, the complete Young equation can be solved:

$(1+\cos \theta)_{\gamma \mathrm{L}}=2\left(\left(\gamma_{\mathrm{S}}^{\mathrm{LW}} \cdot \gamma_{\mathrm{L}}^{\mathrm{LW}}\right)^{\frac{1}{2}}+\left(\gamma_{\mathrm{S}}^{+} \cdot \gamma_{\mathrm{L}}^{-}\right)^{\frac{1}{2}}+\left(\gamma_{\mathrm{L}}^{+} \cdot \gamma_{\mathrm{S}}^{-}\right)^{\frac{1}{2}}\right)$

The interfacial free energy of interaction between two different surfaces ( 1 and 2$)$ in water (w) obeys the Dupré equation:

$\Delta G_{\mathrm{lw} 2}^{\mathrm{LW}+\mathrm{AB}}=\gamma_{12}^{\mathrm{LW}}-\gamma_{1 \mathrm{w}}^{\mathrm{LW}}-\gamma_{2 \mathrm{w}}^{\mathrm{LW}}-\gamma_{12}^{\mathrm{AB}}-\gamma_{1 \mathrm{w}}^{\mathrm{AB}}-\gamma_{2 \mathrm{w}}^{\mathrm{AB}}$

Contact angle measurements. Cells harvested from a midexponential growth phase were washed twice with $0.1 \mathrm{M} \mathrm{NaCl} /$ $0.05 \mathrm{M}$ HEPES, pH 7.4. Cells in the buffer $\left(10 \mathrm{ml}\right.$ with $\left.\mathrm{OD}_{470} 0.4\right)$ were deposited on cellulose acetate membrane filters (pore size, $0.22 \mu \mathrm{m}$; Osmonics) to produce an even bacterial lawn. The cells were washed with Nanopure water and air dried for 30-40 min until socalled 'plateau contact angles' could be measured using water droplets.

Droplets of three liquids (water, formamide and diiodomethane) were applied to each surface (Teflon/glass syringes equipped with
Table 1. Surface tension parameters of the probe liquids

\begin{tabular}{|lllccc|}
\hline Liquid & $\gamma^{\text {TOT }}$ & $\gamma^{\text {LW }}$ & $\gamma^{\text {AB }}$ & $\gamma^{+}$ & $\gamma^{-}$ \\
\hline Water & 72.8 & 21.8 & 51.0 & 25.5 & 25.5 \\
Formamide & 58 & 39 & 19 & 2.28 & 39.6 \\
Diiodomethane & 50.8 & 50.8 & 0 & 0 & 0 \\
\hline
\end{tabular}

24-gauge stainless steel Luer-tipped hypodermic needles; Gilmont Instruments). The surface-tension component values of these liquids are shown in Table 1.

The contact of the drop of the bacterial lawn was observed with an optical microscope equipped with a charge-coupled device (CCD) camera. For static contact angles, the drop was allowed to settle for $2 \mathrm{~s}$ without needle contact. Images were digitally saved, and contact angle values were obtained by processing the images using a program based on the Young-Laplace equation, designed by Joop de Vries, University of Gröningen, The Netherlands. The mean contact angles for each sample were calculated from five droplets (two angles per droplet), measured on different areas of the membrane surface.

Adhesion of bacteria to haematite. Sorption isotherm and adsorption kinetic experiments were carried out in triplicate at $24^{\circ} \mathrm{C}$. Cells were washed as described above and resuspended in $0.1 \mathrm{M} \mathrm{NaCl} /$ $0.05 \mathrm{M}$ HEPES, $\mathrm{pH} 7.4$, to obtain cell concentrations of 50-400 $\mu \mathrm{g}$ dry weight $\mathrm{ml}^{-1}$. Cell suspensions $(10 \mathrm{ml})$ were added to $20 \mathrm{ml}$ vials containing $0.05-0.2 \mathrm{~g}$ haematite. These were agitated at 150 r.p.m. for $40 \mathrm{~min}$, and then left static for $10 \mathrm{~min}$ as coarse mineral particles sedimented. Fine-grained haematite was removed by centrifugation at $130 \mathrm{~g}$, and the final cell concentration was measured at $\mathrm{OD}_{470}$.

Cell dry weight was determined by filtration through $0.22 \mu \mathrm{m}$ poresize membrane filters (Osmonics). Cells were washed twice with $2.5 \mathrm{ml}$ distilled water, and filters were dried at $105^{\circ} \mathrm{C}$ to a constant weight.

Adhesion experiments with DMSO. Cell suspensions were applied to the top of Octyl-Sepharose or Sepharose CL-4B columns, and after $15 \mathrm{~min}$ equilibration, they were eluted with $0.01 \mathrm{M} \mathrm{HEPES/DMSO,}$ $\mathrm{pH} 7.4$, containing $0-50 \%$ DMSO. DMSO $>40 \%$ produced cell adhesion to Sepharose CL-4B, whereas at lower concentrations, the adhesion was insignificant (data not shown). Therefore, for our haematite-adhesion experiments in DMSO, a $40 \%$ solvent concentration was chosen as the upper limit. As before, experiments were performed in vials containing $0.1 \mathrm{~g}$ haematite and $15 \mathrm{ml} 0.01 \mathrm{M}$ HEPES/DMSO (0-40\%), pH 7.4, with $0.2 \mathrm{ml}$ concentrated cell suspension. The stock cell suspension was prepared so that when it was diluted $1: 75$, the final $\mathrm{OD}_{470}$ was 0.6 . Adsorption was estimated from the difference between the optical density of the control vials (containing no haematite) and those with haematite.

Statistical analyses These were performed using OriginPro version 7.5 software (OriginLab).

\section{RESULTS}

\section{HIC/ESIC}

RSH and RSC values for our strains are given in Table 2. A relationship was apparent between these surface properties and those reported in previous studies of cell surface ultrastructure and composition (Korenevsky et al., 2002). 
Table 2. RSC, RSH and zeta potential ( $\zeta)$ of Shewanella cells

ND, Not determined.

\begin{tabular}{|c|c|c|c|c|c|c|c|}
\hline \multirow[t]{2}{*}{ Strain } & \multirow[t]{2}{*}{ LPS type* } & \multirow[t]{2}{*}{ Capsule } & \multirow{2}{*}{$\begin{array}{c}\text { Growth } \\
\text { conditions }\end{array}$} & \multirow[t]{2}{*}{$\mathrm{RSC} \dagger$} & \multirow[t]{2}{*}{$\mathrm{RSH} \neq$} & \multicolumn{2}{|c|}{$\zeta(\mathbf{m V} \pm \mathrm{SEM})$} \\
\hline & & & & & & $0.01 \mathrm{M} \varsigma$ & $0.1 \mathrm{M} \|$ \\
\hline S. putrefaciens CN32 & $\mathrm{R}$ & - & Anaerobic\# & $99.5 \pm 0.6$ & $96 \pm 0.8$ & $33.5 \pm 1.1$ & $17.1 \pm 1.8$ \\
\hline S. putrefaciens CIP8040 & $\mathrm{R}$ & + & Aerobic & $55.0 \pm 2.4$ & $38.0 \pm 2.0$ & $23.0 \pm 1.5$ & $14.4 \pm 2.0$ \\
\hline S. baltica 63 & $\mathrm{R}$ & - & Anaerobic & $95.0 \pm 0.8$ & $80.7 \pm 1.3$ & $33.5 \pm 1.4$ & $15.8 \pm 2.4$ \\
\hline \multirow[t]{2}{*}{ S. oneidensis MR-1 } & \multirow[t]{2}{*}{$\mathrm{R}$} & \multirow[t]{2}{*}{+} & Aerobic & $16.9 \pm 3.7$ & $92.0 \pm 2.2$ & $7.6 \pm 1.1$ & $6.7 \pm 1.1$ \\
\hline & & & Anaerobic & ND & ND & $9.5 \pm 1.6$ & $7.1 \pm 1.9$ \\
\hline \multirow[t]{2}{*}{ S. oneidensis MR-4 } & \multirow[t]{2}{*}{$\mathrm{R}$} & \multirow[t]{2}{*}{+} & Aerobic & $21.6 \pm$ & $33.2 \pm 3.3$ & $23.3 \pm 1.1$ & $12.8 \pm 0.8$ \\
\hline & & & Anaerobic & $8.1 \pm 2.5$ & $18.2 \pm 2.7$ & $25.4 \pm 2.2$ & $14.8 \pm 1.7$ \\
\hline S. oneidensis $\mathrm{MR}-4 \mathrm{r}$ & $\mathrm{R}$ & - & Aerobic & $82.8 \pm 1.7$ & $78.3 \pm 1.1$ & $30.7 \pm 2.5$ & $17.1 \pm 2.7$ \\
\hline \multirow[t]{2}{*}{ S. algae $\mathrm{BrY} \mathrm{Y}^{\mathrm{DLr}}$} & \multirow[t]{2}{*}{$\mathrm{R}$} & \multirow[t]{2}{*}{-} & Aerobic & $100.0 \pm 0$ & $100.0 \pm 0$ & $\mathrm{ND}$ & $16.9 \pm 2.6$ \\
\hline & & & Anaerobic & $82.5 \pm 1.1$ & $86.0 \pm 0.4$ & ND & $17.9 \pm 3.5$ \\
\hline \multirow[t]{2}{*}{ S. algae $\mathrm{BrY}^{\mathrm{FCs}}$} & \multirow[t]{2}{*}{$\mathrm{S}$} & \multirow[t]{2}{*}{+} & Aerobic & $15.3 \pm 3.4$ & $47.9 \pm 2.3$ & $\mathrm{ND}$ & $11.9 \pm 1.7$ \\
\hline & & & Anaerobic & $36.7 \pm 2.8$ & $33.4 \pm 2.9$ & $\mathrm{ND}$ & $14.5 \pm 0.6$ \\
\hline S. algae OK-1 & S & \pm & Aerobic & $64.0 \pm 1.8$ & $90.1 \pm 0.9$ & ND & $16.5 \pm 2.1$ \\
\hline
\end{tabular}

${ }^{\star} \mathrm{R}$, rough LPS; S, smooth LPS.

$\nmid \mathrm{RSC}$ in $0.4 \mathrm{M}$ potassium phosphate.

$\ddagger \mathrm{RSH}$ in $1 \mathrm{M} \mathrm{NaCl}$.

$\$ \mathrm{NaCl}(0.01 \mathrm{M})$ in $0.005 \mathrm{M}$ HEPES, $\mathrm{pH}$ 7.4.

IINaCl $(0.1 \mathrm{M})$ in $0.05 \mathrm{M}$ HEPES, pH 7.4.

$\checkmark$ Bacteria were grown aerobically in TSB.

\#Bacteria were grown anaerobically in CDM with lactate/fumarate.

${ }^{\star *}$ Capsule expression varied between cells in a population.

Rough strains lacking the LPS $O$ side chain or capsular PS displayed strong interactions with hydrophobic OctylSepharose (RSH, 51-100\%), even at low salt concentrations, while encapsulated strains had low affinity to the resin (RSH, 8-55\%). Representative elution curves for the rough strain $S$. putrefaciens $\mathrm{CN} 32$ and encapsulated $S$. putrefaciens CIP 8040 are shown in Fig. 1(a).

ESIC showed that all rough Shewanella strains were highly electronegative, displaying RSC values of $62-100 \%$ (Table 2). As can be seen from Fig. 1(b), $\sim 100 \%$ of the CN32 cells were bound to positively charged DEAESepharose over the full range of phosphate concentrations tested. Smooth and encapsulated strains displayed significantly less electronegativity than did rough strains.

Surface physicochemistry of Shewanella grown under anaerobic conditions followed the same general trend: rough variants were the most hydrophobic and electronegative, while encapsulated strains were the least so. However, anaerobically grown cells possessed lower RSH and RSC values than aerobically grown cells (Table 2).
Mean RSH values $( \pm \mathrm{SD})$ obtained for aerobic and anaerobic conditions were $39.7 \pm 26.8$ for rough and $90.0 \pm 16.5$ for smooth strains. These values were significantly different $(P<0.001)$, as confirmed by one-way ANOVA with Tukey's honestly significant difference test. The same test demonstrated that the RSC values of the two groups of strains $(83.9 \pm 12.9$ and $43.8 \pm 26.7$, respectively) were significantly different $(P<0.005)$. Importantly, no transition between surface hydrophobicity and hydrophilicity was seen in any of the strains when grown under different conditions. There was a good linear correlation between RSC and RSH of Shewanella strains, as can be seen in Fig. 2, suggesting that a common factor influences these two parameters.

\section{Zeta potentials}

Generally, the zeta potentials of all strains followed the pattern found with the ESIC measurements (Table 2). Rough strains were more electronegative than smooth or encapsulated strains. The difference in zeta potential between smooth and rough variants of the same species was 

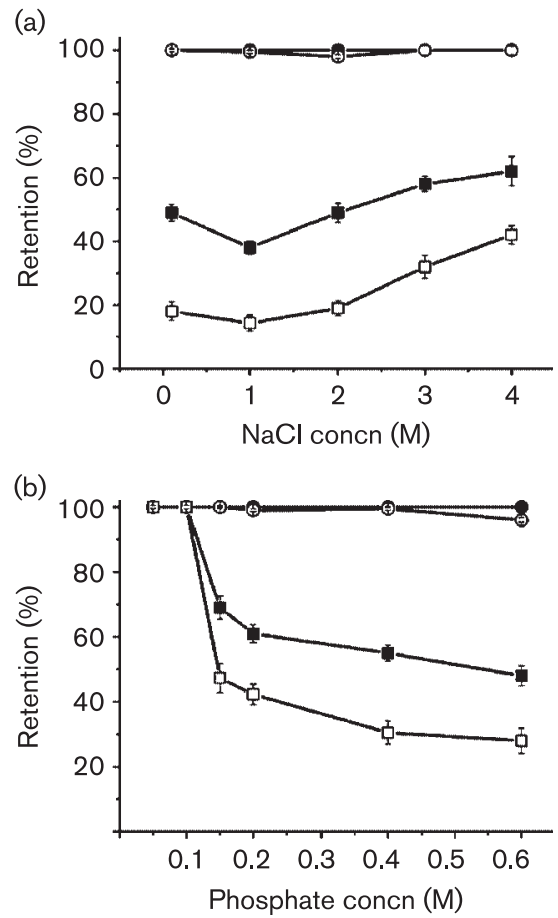

Fig. 1. RSC as determined by HIC (a), and RSC as determined by ESIC (b) of S. putrefaciens CN32 (circles) and S. putrefaciens CIP8040 (squares), grown under aerobic (closed symbols) and anaerobic conditions (open symbols). The data represent the mean \pm SD for three separate experiments.

in the range $30-50 \%$ for aerobically grown and $20-30 \%$ for anaerobically grown cells. Cell surface electronegativity of S. putrefaciens CN32 grown to mid-exponential or earlystationary phase did not vary substantially (data not

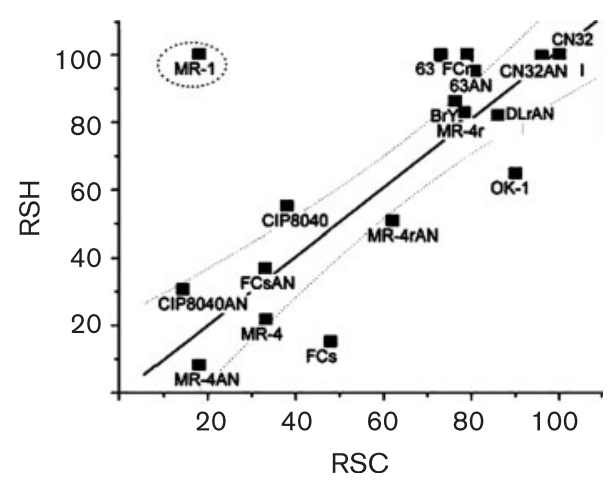

Fig. 2. Relationship between RSC and RSH of Shewanella cells. Cells grown under anaerobic conditions are indicated by the addition of the suffix AN to the strain name. The line demarcates the confidence interval $(P<0.05)$. The results for strain MR-1 were excluded for the reasons explained in the text. shown). For all of the tested cultures, zeta potentials were in good agreement with the ESIC results; values of $\zeta$ and RSC yielded a high correlation coefficient of -0.84 (Table 5).

\section{Contact-angle measurements}

The observed mean contact angles and SE are listed in Table 3. The water contact angles of our strains were in the range $27-45^{\circ}$. Accordingly, by this technique, the overall cell-surface character of all strains was hydrophilic, since angles $>60-65^{\circ}$ denote hydrophobicity (Vogler, 1998). Interestingly, the difference in water contact angles of cells grown aerobically in TSB and anaerobically in CDM was minimal $\left(<5^{\circ}\right)$. Furthermore, encapsulated strains (e.g. MR-4) appeared to be only slightly more hydrophilic than their rough counterparts (MR-4r). No apparent correlation between water contact angles and the RSH values obtained with HIC was established.

Table 3 summarizes surface-tension parameters calculated from contact angles for water, formamide and diiodomethane. All bacterial surfaces displayed very low values $\left(<0.85 \mathrm{~mJ} \mathrm{~m}^{-2}\right)$ for the electron-acceptor parameter, and high values for the electron-donor parameter $\left(>43 \mathrm{~mJ} \mathrm{~m}^{-2}\right.$; most of these organic-solvent values were higher than those for water alone). Such surfaces may be designated as being monopolar and hydrophilic (Van Oss, 1994). As can be seen from Table 3, the haematite surface was also quite hydrophilic. Predictably, calculations of the free energy of interaction between haematite and bacteria in water gave positive values for all tested strains; at the cell-haematite interface, acid-base repulsion (or hydrophilic repulsion) dominated LW attraction. However, the total energy of interaction also contains an electrostatic energy of interaction component, and this suggests that adhesion should take place if attractive electrostatic interactions overcome this repulsive force.

\section{Sorption kinetics and isotherms}

Batch experiments with strains CN32 and MR-4 demonstrated that initial adsorption of bacteria to haematite was a rapid process; most cells were bound within a few minutes (Fig. 3). Equilibrium was reached after approximately $40 \mathrm{~min}$, and the cell concentrations in suspension stabilized at levels that did not change significantly for the next $3 \mathrm{~h}$. All further adsorption experiments were performed using a 40 min contact time.

Equilibrium adhesion experiments were conducted with cells grown under aerobic and anaerobic conditions. The results for two representative strains (rough $\mathrm{CN} 32$ and encapsulated CIP8040) are presented as adsorption isotherms (i.e. as plots of the quantity of bacterial cells retained by haematite, as a function of the cell concentration in the liquid phase that is at equilibrium with the haematite) (Fig. 4). All adsorption curves followed the same general trend; haematite adsorption capacity (or the number of cells adsorbed by haematite) increased and gradually reached saturation point (or plateau) at a certain 
Table 3. Physicochemical properties of Shewanella strains and the free energy of adhesion $\left(\Delta G_{\text {bwh }}\right)$ between bacteria (b) and haematite $(h)$ in water $(w)$

Abbreviations: DIM, diiodomethane; FO, formamide; W, water.

\begin{tabular}{|c|c|c|c|c|c|c|c|c|c|}
\hline \multirow[t]{2}{*}{ Strain } & \multirow{2}{*}{$\begin{array}{c}\text { Growth } \\
\text { conditions }\end{array}$} & \multicolumn{3}{|c|}{ Contact angle (degrees \pm SEM) } & \multicolumn{4}{|c|}{ Surface-tension component $\left(\mathrm{mJ} \mathrm{m}^{-2}\right)$} & \multirow{2}{*}{$\begin{array}{c}\Delta G_{\mathrm{bwh}} \\
\left(\mathrm{mJ} \mathrm{\textrm {m } ^ { - 2 }}\right)\end{array}$} \\
\hline & & $\theta_{\mathrm{W}}$ & $\theta_{\text {DIM }}$ & $\theta_{\mathrm{FO}}$ & $\gamma^{\mathrm{LW}}$ & $\gamma^{+}$ & $\gamma^{-}$ & $\gamma^{\mathrm{AB}}$ & \\
\hline S. putrefaciens $\mathrm{CN} 32$ & Anaerobic $\dagger$ & $33.7 \pm 3.8$ & $62.1 \pm 2.3$ & $56.3 \pm 1.4$ & 27.37 & 0.06 & 70.87 & 4.25 & 50.1 \\
\hline S. putrefaciens CIP8040 & Aerobic & $33.7 \pm 2.7$ & $52.9 \pm 0.9$ & $48.1 \pm 2.1$ & 32.64 & 0.27 & 60.51 & 8.07 & 41.3 \\
\hline S. baltica 63 & Anaerobic & $28.3 \pm 3.1$ & $54.7 \pm 2.2$ & $46.0 \pm 1.4$ & 31.62 & 0.41 & 65.10 & 10.3 & 43.8 \\
\hline \multirow[t]{2}{*}{ S. algae $\mathrm{BrY}$} & Aerobic & $42.2 \pm 2.2$ & $56.7 \pm 0.9$ & $47.9 \pm 2.6$ & 30.47 & 0.68 & 47.37 & 11.4 & 32.8 \\
\hline & Anaerobic & $39.8 \pm 3.1$ & $52.4 \pm 1.3$ & $49.0 \pm 0.9$ & 32.93 & 0.32 & 52.55 & 8.17 & 36.2 \\
\hline \multirow[t]{2}{*}{ S. algae $\mathrm{BrY} \mathrm{Y}^{\mathrm{DLr}}$} & Aerobic & $45.3 \pm 1.6$ & $59.3 \pm 2.6$ & $48.7 \pm 2.3$ & 28.98 & 0.84 & 43.29 & 12.1 & 30.2 \\
\hline & Anaerobic & $40.3 \pm 2.7$ & $47.1 \pm 4.6$ & $49.9 \pm 2.0$ & 35.88 & 0.01 & 53.16 & 1.43 & 37.4 \\
\hline S. algae $\mathrm{BrY}^{\mathrm{FCs}}$ & Aerobic & $37.9 \pm 1.2$ & $68.3 \pm 2.2$ & $55.9 \pm 1.8$ & 23.83 & 0.54 & 63.13 & 11.7 & 45.4 \\
\hline \multirow[t]{2}{*}{ S. oneidensis MR-4r } & Aerobic & $35.5 \pm 2.4$ & $55.2 \pm 2.5$ & $48.2 \pm 1.9$ & 31.33 & 0.42 & 57.88 & 9.82 & 39.7 \\
\hline & Anaerobic & $32.5 \pm 2.2$ & $58.3 \pm 1.9$ & $49.9 \pm 2.4$ & 29.55 & 0.37 & 64.09 & 9.79 & 44.1 \\
\hline \multirow[t]{2}{*}{ S. oneidensis MR-1 } & Aerobic & $30.6 \pm 2.3$ & $63.6 \pm 2.9$ & $51.3 \pm 2.1$ & 26.51 & 0.51 & 68.20 & 11.7 & 47.2 \\
\hline & Anaerobic & $26.8 \pm 1.3$ & $65.6 \pm 1.5$ & $56.4 \pm 2.8$ & 25.36 & 0.11 & 80.70 & 5.98 & 55.7 \\
\hline Haematite $\neq$ & & & & & 45.6 & 0.3 & 50.4 & 7.8 & \\
\hline
\end{tabular}

${ }^{*}$ Bacteria were grown aerobically in TSB.

$\dagger$ Bacteria were grown anaerobically in CDM with lactate/fumarate.

$\neq$ Data from Costanzo et al. (1995).

cell concentration. The shape of the isotherms indicated that the data could be described by the Langmuir equation: $\mathrm{Q}=Q_{\mathrm{m}}{ }^{*} C_{\mathrm{eq}} /\left(K_{\mathrm{s}}+C_{\mathrm{eq}}\right)$

where $Q_{m}$ is the maximum adsorption capacity after complete saturation of the surface, $K_{\mathrm{s}}$ is the adsorption

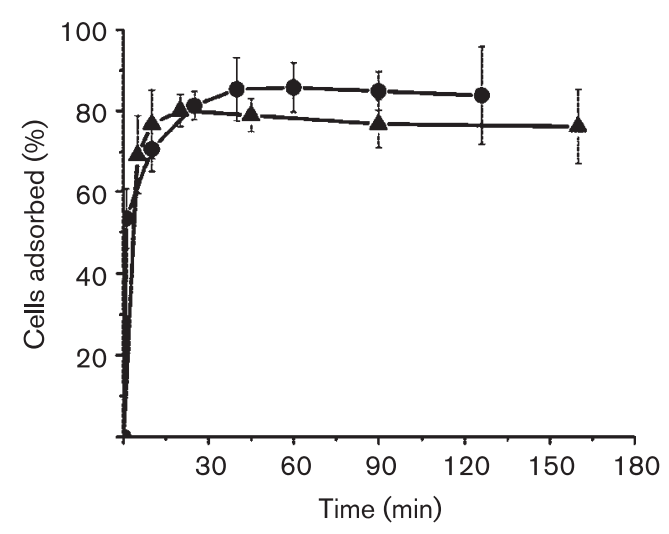

Fig. 3. Dynamics of adsorption of S. putrefaciens CN32 (0) and S. oneidensis MR-4 (A) to haematite. The data represent the mean \pm SD for three separate experiments. constant related to the energy of adsorption, and $C_{\mathrm{eq}}$ is the equilibrium concentration of bacterial cells.

The Langmuir equation fitted the experimental data reasonably well, yielding two parameters $\left(Q_{\mathrm{m}}\right.$ and $\left.K_{\mathrm{s}}\right)$ which reflect important characteristics of the adsorption

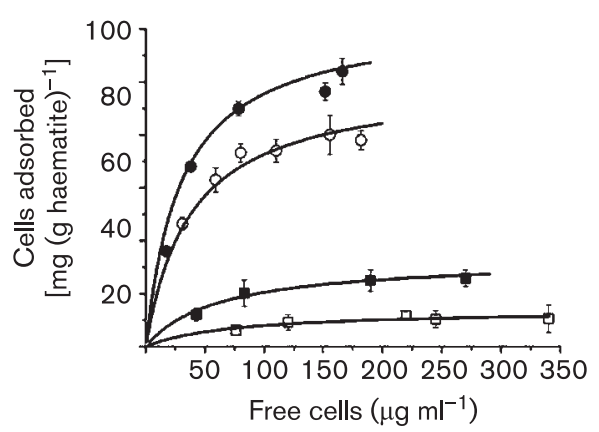

Fig. 4. Adsorption isotherms of $S$. putrefaciens CN32 (circles) and S. putrefaciens CIP8040 (squares), grown under aerobic (closed symbols) and anaerobic conditions (open symbols) with haematite. In the latter case, adhesion experiments were performed anaerobically under a nitrogen atmosphere. The data represent the mean \pm SD for three separate experiments. 
Table 4. Langmuir parameters $( \pm$ SEM) for the adsorption of Shewanella cells onto haematite

\begin{tabular}{|c|c|c|c|c|}
\hline Strain & Growth conditions & $Q_{m}\left(\mathrm{mg} \mathrm{g}^{-1}\right)$ & $K_{\mathrm{s}}\left(\mu \mathrm{g} \mathrm{ml}^{-1}\right)$ & $R^{2}$ \\
\hline \multirow[t]{2}{*}{ S. putrefaciens $\mathrm{CN} 32$} & Aerobic $^{*}$ & $62.2 \pm 3.3$ & $24.9 \pm 6.1$ & 0.98 \\
\hline & Anaerobic $\dagger$ & $46.8 \pm 1.7$ & $28.7 \pm 4.3$ & 0.99 \\
\hline \multirow[t]{2}{*}{ S. putrefaciens CIP8040 } & Aerobic & $17.5 \pm 1.9$ & $70.5 \pm 19.0$ & 0.99 \\
\hline & Anaerobic & $7.0 \pm 0.9$ & $74.8 \pm 33.0$ & 0.96 \\
\hline \multirow[t]{2}{*}{ S. baltica 63} & Aerobic & $47.0 \pm 1.5$ & $49.3 \pm 5.3$ & 0.99 \\
\hline & Anaerobic & $40.7 \pm 4.1$ & $44.0 \pm 16.3$ & 0.96 \\
\hline \multirow[t]{2}{*}{ S. oneidensis MR-4 } & Aerobic & $5.3 \pm 0.7$ & $100.1 \pm 30.0$ & 0.99 \\
\hline & Anaerobic & $8.5 \pm 1.4$ & $68.1 \pm 34.7$ & 0.92 \\
\hline \multirow[t]{2}{*}{ S. oneidensis $\mathrm{MR}-4 \mathrm{r}$} & Aerobic & $41.9 \pm 4.0$ & $32.2 \pm 11.8$ & 0.97 \\
\hline & Anaerobic & $31.4 \pm 5.1$ & $49.5 \pm 26.4$ & 0.94 \\
\hline S. oneidensis MR-1 & Aerobic & $29.2 \pm 3.1$ & $2.6 \pm 1.2$ & 0.93 \\
\hline S. algae OK-1 & Aerobic & $45.6 \pm 2.5$ & $9.3 \pm 2.6$ & 0.98 \\
\hline S. algae $\mathrm{BrY}$ & Aerobic & $32.2 \pm 1.3$ & $17.3 \pm 4.6$ & 0.97 \\
\hline \multirow[t]{2}{*}{ S. algae $\mathrm{BrY}^{\mathrm{DLr}}$} & Aerobic & $51.2 \pm 1.3$ & $18.9 \pm 2.0$ & 0.99 \\
\hline & Anaerobic & $34.8 \pm 1.6$ & $21.0 \pm 4.4$ & 0.99 \\
\hline \multirow[t]{2}{*}{ S. algae $\mathrm{BrY}^{\mathrm{FCs}}$} & Aerobic & $9.4 \pm 0.3$ & $79.3 \pm 10.8$ & 0.99 \\
\hline & Anaerobic & $8.9 \pm 1.3$ & $64.6 \pm 38$ & 0.96 \\
\hline
\end{tabular}

${ }^{*}$ Bacteria were grown aerobically in TSB.

$\dagger$ Bacteria were grown anaerobically in CDM with lactate/fumarate.

system and allow quantitative comparison of the isotherms (Table 4). The highest adsorption affinity and capacity of haematite were observed for rough strains. Encapsulated strains displayed the lowest adhesion, with their corresponding adsorption parameters differing by more than one order of magnitude from those of some rough strains. This suggests that smooth and encapsulated Shewanella are not as readily adhesive for haematite surfaces. Interestingly, for most cases, anaerobically grown cells exhibited lower adsorption capacity and affinity for haematite than cells grown under aerobic conditions (Fig. 4, Table 4).

\section{Correlation between surface properties and adhesion to haematite}

The Langmuir values were used to determine the correlation between adhesion and bacterial surface properties (Table 5). This and Fig. 5 show that there was a strong correlation between cell-surface charge and the $Q_{\mathrm{m}}$ and $K_{\mathrm{s}}$ Langmuir parameters $\left(r^{2} 0.88\right.$ and 0.76 , respectively). Unlike most strains, S. oneidensis MR-1 exhibited very low surface charge and high affinity to haematite $\left(K_{\mathrm{s}} 3.9 \mathrm{mg}^{-1}\right)$

Table 5. Pearson correlation coefficients $(r)$ between Shewanella cell-surface properties and Langmuir (adsorption) parameters

\begin{tabular}{|lcccr|}
\hline Parameter & RSC & RSH & $\boldsymbol{Q}_{\mathbf{m}}$ & \multicolumn{1}{c|}{$\boldsymbol{K}_{\mathbf{s}}$} \\
\hline RSC & - & 0.88 & 0.94 & -0.87 \\
RSH & 0.88 & - & 0.85 & -0.79 \\
$\zeta$ & 0.84 & -0.83 & -0.89 & 0.84 \\
\hline
\end{tabular}

(Fig. 5). Because this value deviated so far from the trend of the other strains, it was excluded from correlation analysis.

Cell-surface hydrophobicity produced a looser positive correlation with adhesion parameters $Q_{\mathrm{m}}$ and $K_{\mathrm{s}}\left(r^{2} 0.72\right.$ and 0.62 , respectively). However, this correlation apparently held true and overlapped all strains, since RSH and RSC are interrelated $\left(r^{2}\right.$ 0.77). For this reason, first-order partial correlations were calculated (Table 6). Correlations between adsorption parameters and cell-surface charge remained significant when the influence of surface hydrophobicity was constrained. In contrast, the robust bivariate correlations between $\mathrm{RSH}, Q_{\mathrm{m}}$ and $K_{\mathrm{s}}$ were dramatically reduced when the RSC parameter was held constant. This trend suggested that the bivariate correlations between $\mathrm{RSH}$ and Langmuir parameters were artefacts of the relationship between RSH and RSC.

\section{Influence of DMSO on the interaction of strain CN32 with Octyl-Sepharose and haematite}

To ensure that electrostatic forces between Shewanella and haematite prevailed over hydrophobic interactions, we conducted adhesion experiments in DMSO. DMSO is a water-miscible liquid with a low $\gamma^{\mathrm{AB}}$ parameter (i.e. $\sim 0 \mathrm{~mJ}$ $\mathrm{m}^{-2}$, therefore, $\gamma^{\mathrm{TOT}}=\gamma^{\mathrm{LW}}=44 \mathrm{~mJ} \mathrm{~m}{ }^{-2}$ ). Once present, it decreases hydrophobic interactions, reducing the $\gamma^{\text {TOT }}$ of the suspending medium (Van Oss et al., 1986).

In these experiments, we used $\mathrm{CN} 32$, one of the most hydrophobic Shewanella strains, to ensure maximum hydrophobic interaction with haematite. Octyl-Sepharose was used as a model hydrophobic substrate for a positive 
(a)

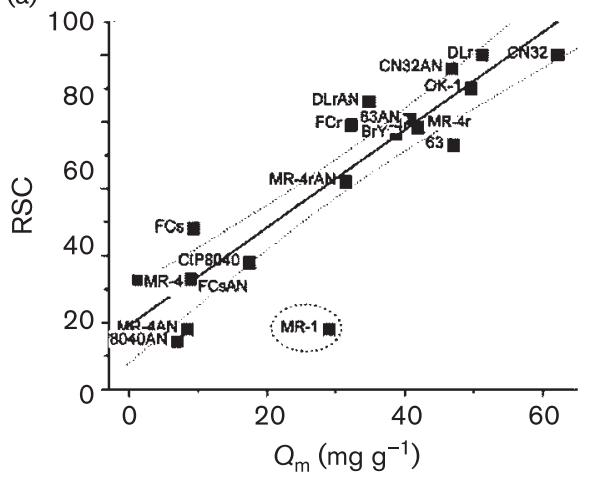

(b)

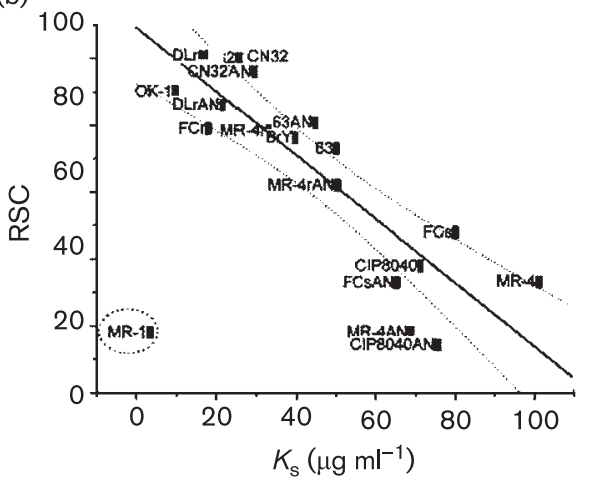

(a)

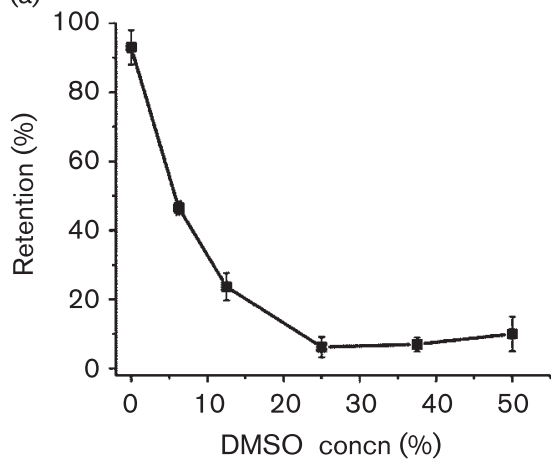

(b)

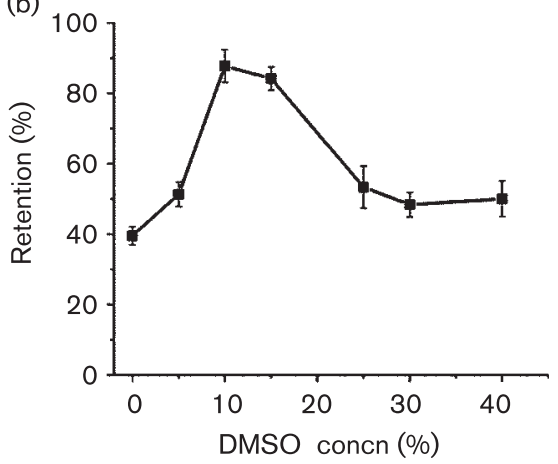

Fig. 5. Relationship between RSC and Langmuir parameters $Q_{m}$ (a) and $K_{s}$ (b) for the adsorption of Shewanella cells onto haematite. Cells grown under anaerobic conditions are indicated by adding the suffix AN to the strain name. The lines demarcate the confidence intervals $(P<0.05)$. The results for strain MR-1 were excluded for the reasons explained in the text.

control. As can be seen from Fig. 6, cells were progressively eluted from the Octyl-Sepharose column, and $<10 \%$ were retained with $\sim 25 \%$ DMSO. However, DMSO did not reduce cell adhesion to haematite (Fig. 6). Instead, adhesion significantly increased with increasing DMSO concentration up to $10 \%$, and then gradually decreased. Even so, adhesion was higher than when DMSO was not present.

\section{DISCUSSION}

In this study, we assessed the hydrophilic or hydrophobic nature of Shewanella using a variety of disparate techni-

Table 6. First order partial correlations $(r), t$ values and their associated significance levels $(P)$

\begin{tabular}{|lccc|}
\hline Parameters & $\boldsymbol{r}$ & $\boldsymbol{t}$ & $\boldsymbol{P}$ \\
\hline RSC $: Q_{\mathrm{m}}$ RSH & 0.73 & 3.90 & 0.0018 \\
RSH : $Q_{\mathrm{m}}$ RSC & 0.32 & 1.24 & 0.2369 \\
RSC $: K_{\mathrm{s}}$ RSH & 0.58 & 2.58 & 0.0229 \\
RSH $: K_{\mathrm{s}}$ RSC & 0.15 & 0.54 & 0.5983 \\
\hline
\end{tabular}

Fig. 6. Influence of DMSO on adsorption of $S$. putrefaciens CN32 to Octyl-Sepharose (a) and haematite (b). The data represent the mean \pm SD for three separate experiments.

ques, and demonstrated that the cell surface of most Shewanella strains is quite electronegative and hydrophilic. These traits are clearly affected by LPS and capsular PS, since strains expressing rough LPS and no PS were more hydrophobic and electronegative than smooth or encapsulated strains. Certainly, OMPs, which usually do not extend as far from the membrane surface as LPS, should also be factors capable of controlling surface physicochemistry, but these proteins were not studied here.

We must stress that we studied the process of initial adhesion, which takes place in the first minutes of the cellmineral interaction, and is governed by cell and mineral surface physicochemistry. Therefore, the influence of factors inducible by cell-surface contact, e.g. upregulation of surface PS/OMP expression, on bacterial adhesion to iron oxide was not the aim of our study.

Two different methods, contact angles and HIC, were employed for the assessment of cell-surface hydrophobicity. The first method, contact angle measurement, yielded quantitative parameters of cell-surface hydrophobicity, and assessed the surface free energy using the LW/Lewis acidbase approach. Here, measurements showed the overall character of all Shewanella surfaces to be hydrophilic, with low electron-acceptor capacity but with high electrondonor parameters. The second method, HIC, was chosen as the least perturbing protocol for cell-surface analysis, since 
it measures live bacteria in their natural fully hydrated state (Pembrey et al., 1999). It is based on the interaction of a bacterium with a hydrophobic substrate (Octyl-Sepharose), and appeared to be much more sensitive to ultrastructural variations of the bacterial surfaces than were contact angle measurements. The HIC values of Shewanella showed a strong relationship with known LPS/PS composition and were in good agreement with previous studies, in which increased cell-surface hydrophobicity was found in strains expressing short $O$ side chains or rough LPS (Hermansson et al., 1982; Williams et al., 1986; Makin \& Beveridge, 1996; Williams \& Fletcher, 1996; Flemming et al., 1998; Razatos et al., 1998; DeFlaun et al., 1999). The higher hydrophobicity of rough strains is considered to be a consequence of increased exposure of hydrophobic OMPs. The high hydrophobicity of S. algae BrY, OK-1 and MR-1 expressing either smooth LPS or capsules can be explained by the irregular patchiness of their $O$ side chains and PS (Korenevsky et al., 2002).

ESIC and zeta potential provided information on cellsurface electronegativity and were in good agreement with one another. Both measurements showed that the presence of either smooth LPS or capsular PS decreased cell-surface electronegativity. Although encapsulated bacteria are often reported to be more electronegative than those with rough LPS phenotypes, the opposite was found with our Shewanella strains. This new tendency has been previously reported for a number of Gram-negative bacteria (Hermansson et al., 1982; Flemming et al., 1998; Makin \& Beveridge, 1996). Our recent LPS/PS structural analyses have helped to explain the present electronegativity results (Vinogradov et al., 2002, 2003a, b, 2004, 2005). The common repeating motif of the $S$. algae $\mathrm{BrY} O$ side chain consists of four monosaccharides and contains 3-hydroxybutyric acid and malic acid. Here, the carboxyl group of malic acid is the only available ionizable group in the structure (Vinogradov et al., 2003a). A similar situation has been observed in the capsular PS of S. oneidensis MR-4, in which the pentasaccharide repeating unit contains only one glucuronic acid as an ionizable residue (Vinogradov et al., 2005). In contrast, the core oligosaccharides of Shewanella have been found to be highly phosphorylated (Moule et al., 2004; Vinogradov et al., 2002, 2003b, 2004), and are thus strongly electronegative at circumneutral $\mathrm{pH}$. The $O$ side chains and PS of Shewanella are only weakly charged and are capable of screening the charge located in the core-lipid A region of LPS.

Unlike most other Shewanella strains, MR-1 possesses a surprisingly low surface charge (just a few $\mathrm{mV}$ at circumneutral $\mathrm{pH}$ and an ionic strength of 0.01 ), even though it expresses rough LPS. The reason for such low electronegativity of MR-1 is not completely clear. The core of its LPS contains an unusual component, 8-amino-3-deoxy-Dmanno-octulosonic acid (8-amino-Kdo) (Vinogradov et al., 2003b), which may account for the lowered surface charge, since the amino group masks the carboxylate, which is usually available in other Gram-negative bacteria. This strain possesses a microcapsule of $20-30 \mathrm{~nm}$, which, like the PSs of $S$. oneidensis MR-4, can possess a low charge density (Korenevsky et al., 2002). Yet, the surface charge of MR-4 was several-fold higher than that of MR-1; furthermore, MR-4r, the rough variant of MR-4, exhibited a zeta potential in the same range (approximately $-30 \mathrm{mV}$ ) as other rough Shewanella strains.

S. oneidensis MR-1 with its known genome is currently the most characterized strain, and has become a model organism for studying microbial iron-oxide reduction. Nevertheless, its low surface charge not only substantially deviates from that of the other Shewanella strains, including S. oneidensis, but is also unusual for a Gramnegative bacterium. Interestingly, the zeta potential of Geobacter is similar to that of most Shewanella (unpublished data).

At first, it seems to be a contradiction that HIC experiments suggest that the more polar (electronegative) strains are more hydrophobic than the less electronegative strains. The answer to this contradiction may reside in our traditional perception of $\mathrm{OM}$ structure and the arrangement of surface macromolecules. We too often consider this membrane to be a homogeneous static assembly of macromolecules that are randomly dispersed over the bilayer surface. Instead, all molecules are in dynamic motion and it is probable that, at distinct time intervals, a mosaic of molecular patches of definite polarity and charge exists (Amro et al., 2000; Sokolov et al., 2001; Korenevsky et al., 2002; Vadillo-Rodriguez et al., 2004a). Given an inanimate surface of consistent hydrophobicity (such as the HIC Sepharose beads), the tendency of the OM surface would be to congregate and align compatible macromolecules towards the inanimate surface. Therefore, although the overall Shewanella surface was found to be hydrophilic by other analyses (such as contact angle measurements), it still may be capable of hydrophobic interactions through such apolar congregations. This would lead to adhesion to hydrophobic substrata such as that seen in the HIC experiments. If so, HIC is quite sensitive to such nanoscale cell-surface heterogeneity. ESIC may also use similar CMSepharose beads, but in this case, they are negatively charged since they are cation exchangers. One would then expect that a similar migration of macromolecules would occur but here, the congregation would be of positively charged polar patches. Interestingly, this was exactly what happened. Despite having a net negative surface charge, bacteria were still retained by the negatively charged surface of the beads, presumably due to interaction with a minor number of positively charged sites on the cell surface (Hermansson et al., 1982; Stenström, 1989; Gannon et al., 1991; Pembrey et al., 1999). Cell-surface nanoscale heterogeneity is currently under vigorous investigation, often using AFM, with which individual cells and even small regions of the cell surface can be probed. Thermodynamic approaches, which operate with bulk samples and overall (macroscopic) cell-surface properties (such as surface tension and zeta potential), often fail to 
adequately describe bacterial interactions with surfaces. It is quite possible that cell-surface physicochemical and structural heterogeneity play a significant role in bacterial adhesion (Busscher et al., 2000; Lower et al., 2001; Sokolov et al., 2001; Vadillo-Rodríguez et al., 2004b, 2005).

In our present study, a strong correlation between such macroscopic surface parameters as surface negativity, relative hydrophobicity and adhesion to haematite was observed. Rough Shewanella exhibited affinity and maximal adsorption capacity to haematite more than an order of magnitude higher than those of encapsulated strains. As shown previously, both surface electronegativity and relative hydrophobicity are related, since they are determined by the same surface-structural factor, LPS (Makin \& Beveridge, 1996). Correlation analysis allowed us to rule out the hydrophobicity parameter and conclude that adhesion of Shewanella to haematite is governed by electrostatic interactions. The thermodynamic approach also provided the same result. Calculated interfacial free energy indicated a strong hydrophilic repulsion between the two overall hydrophilic surfaces (i.e. cell surface and haematite surface). The total interaction energy, though, incorporates an electrostatic term, which helps to determine adhesion, since Shewanella cells and haematite (PZC, 8.5) are oppositely charged at circumneutral $\mathrm{pH}$. This is in accord with acid-base titrations, which have demonstrated that hydrous ferric oxide interacts directly with carboxylic sites on the surface of S. putrefaciens CN32 (Martinez et al., 2003; Smith \& Ferris, 2003).

DMSO reduces the surface tension of a suspending medium $\left(\gamma_{\mathrm{LV}}\right)$ and therefore decreases hydrophobic interactions within the system (Absolom et al., 1983; Van Oss et al., 1986). As suspected, DMSO profoundly decreased the affinity of $S$. putrefaciens CN32 to hydrophobic OctylSepharose but had virtually the opposite effect on bacterial adhesion to haematite. It follows that hydrophobic interactions do not make a significant contribution to the adhesion of Shewanella to haematite.

In our present study, results were obtained from bacteria grown either aerobically on a relatively rich TSB medium (so that we could relate our data to previously reported cell-surface ultrastructure and LPS composition; Korenevsky et al., 2002), or anaerobically on CDM with fumarate as the terminal electron acceptor. Importantly, adhesion correlated well with electronegativity for all Shewanella (except for MR-1) grown under such a wide range of environmental conditions. There was another common trend: bacterial adhesion to haematite increased with increasing cell-surface charge.

It is well known that, under anaerobic conditions, Shewanella express elevated amounts of cytochromes and other OMPs that are implicated in the respiration and iron-oxide reduction of the bacterium (Myers \& Myers, 1992; Ruebush et al., 2006). One would expect a more hydrophobic surface on such cells, since surface-associated proteins are usually considered a main factor in determining cell-surface hydrophobicity. However, we found that anaerobically grown cells appeared more hydrophilic and less electronegative than aerobically grown cells. Similarly, in another study, it has been demonstrated using acid-base titration that $S$. putrefaciens $200 \mathrm{R}$ grown under anaerobic conditions with ferric iron as electron acceptor exhibits lower cell-surface site density than aerobically grown cells (Haas, 2004). It is possible that surface-associated proteins in Shewanella are uniquely more hydrophilic than those of other Gram-negative bacteria. These, in combination with other surface macromolecules, provide a general hydrophilicity to the surface.

We did not detect changes in LPS profiles during SDSPAGE silver staining of our strains grown under aerobic and anaerobic conditions in CDM (data not shown). NMR analysis of the chemical structure of the $O$ side chain of LPS from S. algae $\mathrm{BrY}$ and its smooth variant $\left(\mathrm{BrY}^{\mathrm{FCs}}\right)$ reveals no differences in aerobic (grown in either TSB or CDM with lactate) and anaerobic (grown in CDM lactatefumarate medium) cells (E. Vinogradov and others, unpublished data). Similarly, the only difference in the capsular PSs of S. oneidensis MR-4 grown under these conditions lies in the methylation of the 3-hydroxybutyrate residue, which increases the hydrophobic potential of the capsule (Vinogradov et al., 2005).

Often, previous publications have relied on only one or two methodologies of cell physicochemistry assessment, which can be misleading. In contrast, the conclusions from our present study are drawn from a wide range of different techniques, together with recent structural analyses of LPS and PS, and TEM observations (Glasauer et al., 2001; Korenevsky et al., 2002; Vinogradov et al., 2002, 2003a, b, 2004, 2005). Clearly, the issue of surface physicochemistry and its relationship with cell adhesion to iron oxides is complicated, but surface PSs are certainly implicated. Clear trends could be seen that depended on each strain possessing a specific LPS or PS phenotype. Indeed, in this respect, Shewanella is not so far removed from other Gram-negative bacteria that rely on such PSs for surface properties, and the trends seen in the present study may be applicable to these bacteria too.

\section{ACKNOWLEDGEMENTS}

This research was supported by grants to T. J. B. from the Natural and Accelerated Bioremediation Research (NABIR) Program of the US Department of Energy (DOE) under grant \#DE-FG02-99ER62730 and the Pacific Northwest National Laboratory (PNNL)/Environmental Molecular Sciences Laboratory (EMSL) Biogeochemistry Grand Challenge Program, which is also funded through the US DOE. We wish to especially thank Rossman Giese and Carel van Oss from the Departments of Geology and Microbiology, respectively, State University of New York at Buffalo, NY, USA, for their hospitality and help with contact angle measurements. The authors appreciate input from David Fowle of the Department of Earth Sciences, University of Windsor, ON, Canada, regarding zeta potential measurements, and we thank Yuri Gorby of the Pacific Northwest National Laboratory, Richland, WA, USA, for his input to this article. 


\section{REFERENCES}

Absolom, D. R., Lamberti, F. V., Policova, Z., Zingg, W., Van Oss, C. J. \& Neumann, A. W. (1983). Surface thermodynamics of bacterial adhesion. Appl Environ Microbiol 46, 90-97.

Amro, N. A., Kotra, L. P., Wadu-Mesthrige, K., Bulychev, A., Mobashery, S. \& Liu, G. (2000). High-resolution atomic force microscopy studies of the Escherichia coli outer membrane: structural basis for permeability. Langmuir 16, 2789-2796.

Arnold, R. G., DiChristina, T. J. \& Hoffmann, M. R. (1988). Reductive dissolution of $\mathrm{Fe}$ (III) oxides by Pseudomonas sp. 200. Biotechnol Bioeng 32, 1081-1096.

Beliaev, A. S., Saffarini, D. A., McLaughlin, J. L. \& Hunnicutt, D. (2001). MtrC, an outer membrane decaheme c cytochrome required for metal reduction in Shewanella putrefaciens MR-1. Mol Microbiol 39, 722-730.

Beveridge, T. J. (1999). Structures of Gram-negative cell walls and their derived membrane vesicles. J Bacteriol 181, 4725-4733.

Busscher, H. J., Bos, R., Van der Mei, H. C. \& Handley, P. S. (2000). Physicochemistry of microbial adhesion from overall approach to the limits. In Physical Chemistry of Biological Interfaces, pp. 431-458. Edited by A. Baszkin \& W. Norde. New York: Marcel Dekker.

Caccavo, F., Jr (1999). Protein-mediated adhesion of the dissimilatory $\mathrm{Fe}(\mathrm{III})$-reducing bacterium Shewanella alga $\mathrm{BrY}$ to hydrous ferric oxide. Appl Environ Microbiol 65, 5017-5022.

Caccavo, F., Jr, Frolund, B., Van Ommen Kloeke, F. \& Nielsen, P. H. (1996). Deflocculation of activated sludge by the dissimilatory $\mathrm{Fe}(\mathrm{III})$ reducing bacterium Shewanella alga BrY. Appl Environ Microbiol 62, 1487-1490.

Caccavo, F., Jr, Schamberger, P. C., Keiding, K. \& Nielsen, P. H. (1997). Role of hydrophobicity in the adhesion of the dissimilatory $\mathrm{Fe}(\mathrm{III})$-reducing bacterium Shewanella alga BrY to amorphous $\mathrm{Fe}(\mathrm{III})$ oxide. Appl Environ Microbiol 63, 3837-3843.

Costanzo, P. M., Wu, W., Giese, R. F., Jr \& Van Oss, C. J. (1995). Comparison between direct contact angle measurements and thin layer wicking on synthetic monosized cuboid hematite particles. Langmuir 11, 1827-1830.

Das, A. \& Caccavo, F., Jr (2000). Dissimilatory Fe(III) oxide reduction by Shewanella alga BrY requires adhesion. Curr Microbiol 40, 344-347.

DeFlaun, M. F., Oppenheimer, S. R., Streger, S., Condee, C. W. \& Fletcher, M. (1999). Alterations in adhesion, transport, and membrane characteristics in an adhesion-deficient pseudomonad. Appl Environ Microbiol 65, 759-765.

Flemming, C. A., Palmer, P. J., Jr, Arrage, A. A., Van der Mei, H. C. \& White, D. C. (1998). Cell surface physicochemistry alters biofilm development of Pseudomonas aeruginosa lipopolysaccharide mutants. Biofouling 13, 213-231.

Fredrickson, J. K., Zachara, J. M., Kennedy, D. W., Dong, H., Onstott, T. C., Hinman, N. W. \& Li, S. (1998). Biogenic iron mineralization accompanying the dissimilatory reduction of hydrous ferric oxide by a groundwater bacterium. Geochim Cosmochim Acta 62, 3239-3257.

Gannon, J. T., Manilal, V. B. \& Alexander, M. (1991). Relationship between cell surface properties and transport of bacteria through soil. Appl Environ Microbiol 57, 190-193.

Gaspard, S., Vazquez, F. \& Holliger, C. (1998). Localization and solubilization of the iron(III) reductase of Geobacter sulfurreducens. Appl Environ Microbiol 64, 3188-3194.

Glese, R. F. \& Van Oss, C. J. (2002). Surface thermodynamic properties of minerals. In Colloid and Surface Properties of Clays and
Related Minerals. Surfactant Science Series, vol. 105, pp. 229-249. Edited by A. T. Hubbard. New York: Marcel Dekker.

Glasauer, S., Langley, S. \& Beveridge, T. J. (2001). Sorption of Fe (hydr)oxides to the surface of Shewanella putrefaciens: cell-bound fine-grained minerals are not always formed de novo. Appl Environ Microbiol 67, 5544-5550.

Grantham, M. C., Dove, P. M. \& DiCristina, T. J. (1997). Microbially catalyzed dissolution of iron and aluminum oxyhydroxide mineral surface coatings. Geochim Cosmochim Acta 61, 4467-4477.

Haas, J. R. (2004). Effects of cultivation conditions on acid-base titration properties of Shewanella putrefaciens. Chem Geol 209, 67-81.

Hermansson, M., Kjelleberg, S., Korhonen, T. K. \& Stenström, T.-A. (1982). Hydrophobic and electrostatic characterization of surface structures of bacteria and its relationship to adhesion to an air-water interface. Arch Microbiol 131, 308-312.

Korenevsky, A. A., Vinogradov, E., Gorby, Y. \& Beveridge, T. J. (2002). Characterization of the lipopolysaccharides and capsules of Shewanella spp. Appl Environ Microbiol 68, 4653-4657.

Kosmulski, M. J. (2001). Surface charging in absence of strongly adsorbing species. In Chemical Properties of Material Surfaces, Surfactant Science Series, vol. 102, pp. 65-309. Edited by A. T. Hubbard. New York: Marcel Dekker.

Kosmulski, M. (2006). pH-dependent surface charging and points of zero charge. III. Update. J Colloid Interface Sci 298, 730-741.

Lovley, D. R. \& Woodward, J. C. (1996). Mechanisms for chelator stimulation of microbial $\mathrm{Fe}(\mathrm{III})$-oxide reduction. Chem Geol 132, 19-34.

Lovley, D. R., Fraga, J. L., Blun-Harris, E. L., Hayes, L. A., Phillips, E. J. P. \& Coates, J. D. (1998). Humic substances as a mediator for microbially catalyzed metal reduction. Acta Hydrochim Hydrobiol 26, 152-157.

Lovley, D. R., Holmes, D. E. \& Nevin, K. P. (2004). Dissimilatory $\mathrm{Fe}(\mathrm{III})$ and $\mathrm{Mn}(\mathrm{IV})$ reduction. Adv Microb Physiol 49, 219-286.

Lower, S. K., Hochella, M. F., Jr \& Beveridge, T. J. (2001). Bacterial recognition of mineral surfaces: nanoscale interactions between Shewanella and $\alpha-\mathrm{FeOOH}$. Science 292, 1360-1363.

MacDonald, K. L. \& Beveridge, T. J. (2002). Bactericidal effect of gentamicin-induced membrane vesicles derived from Pseudomonas aeruginosa PAO1 on Gram-positive bacteria. Can J Microbiol 48, 810-820.

Makin, S. A. \& Beveridge, T. J. (1996). The influence of A-band and B-band lipopolysaccharide on the surface characteristics and adhesion of Pseudomonas aeruginosa to surfaces. Microbiology 142, 299-307.

Martinez, R. E., Smith, D. S., Pedersen, K. \& Ferris, F. G. (2003). Surface chemical heterogeneity of bacteriogenic iron oxides from a subterranean environment. Environ Sci Technol 37, 5671-5677.

Mehta, T., Coppi, M. V., Childers, S. E. \& Lovley, D. R. (2005). Outer membrane $c$-type cytochromes required for $\mathrm{Fe}(\mathrm{III})$ and $\mathrm{Mn}(\mathrm{IV})$ oxide reduction in Geobacter sulfurreducens. Appl Environ Microbiol 71, 8634-8641.

Moule, A. L., Galbraith, L., Cox, A. D. \& Wilkinson, S. G. (2004). Characterization of a tetrasaccharide released on mild acid hydrolysis of LPS from two rough strains of Shewanella species representing different DNA homology groups. Carbohydr Res 339, 1185-1188.

Myers, C. R. \& Myers, J. M. (1992). Localization of cytochromes to the outer membrane of anaerobically grown Shewanella putrefaciens MR-1. J Bacteriol 174, 3429-3438.

Myers, C. R. \& Myers, J. M. (2004). The outer membrane cytochromes of Shewanella oneidensis MR-1 are lipoproteins. Lett Appl Microbiol 39, 466-470. 
Myers, C. R. \& Nealson, K. H. (1988). Bacterial manganese reduction and growth with manganese oxide as a sole electron acceptor. Science 240, 1319-1321.

Nevin, K. P. \& Lovley, D. R. (2002). Mechanisms for accessing insoluble $\mathrm{Fe}(\mathrm{III})$ oxide during dissimilatory $\mathrm{Fe}(\mathrm{III})$ reduction by Geothrix fermentans. Appl Environ Microbiol 68, 2294-2299.

Nevin, K. P. \& Lovley, D. R. (2002). Mechanisms for Fe(III) oxide reduction in sedimentary environments. Geomicrobiol J 19, 141-159.

Newman, D. K. \& Kolter, R. (2000). A role for excreted quinones in extracellular electron transfer. Nature 405, 94-97.

Pembrey, R. S., Marshall, K. C. \& Schneider, R. P. (1999). Cell surface analysis techniques: what do cell preparation protocols do to cell surface properties? Appl Environ Microbiol 65, 2877-2894.

Razatos, A., Ong, Y. L., Sharma, M. M. \& Georgiou, G. (1998). Molecular determinants of bacterial adhesion monitored by atomic force microscopy. Proc Natl Acad Sci U S A 95, 11059-11064.

Reguera, G., McCarthy, K. D., Mehta, T., Nicoll, J. S., Tuominen, M. T. \& Lovley, D. R. (2005). Extracellular electron transfer via microbial nanowires. Nature 435, 1098-1101.

Ruebush, S. S., Icopini, G. A., Brantley, S. L. \& Tien, M. (2006). In vitro enzymatic mineral oxide reduction by membrane fractions from Shewanella oneidensis MR-1. Geochim Cosmochim Acta 70, 56-70.

Smith, D. S. \& Ferris, F. G. (2003). Specific surface chemical interactions between hydrous ferric oxide and iron-reducing bacteria determined using pK(a) spectra. J Colloid Interface Sci 266, 60-67.

Sokolov, I., Smith, D. S., Henderson, G. S., Gorby, Y. A. \& Ferris, F. G. (2001). Cell surface electrochemical heterogeneity of the Fe(III)-reducing bacteria Shewanella putrefaciens. Environ Sci Technol 35, 341-347.

Stenström, T. A. (1989). Bacterial hydrophobicity, an overall parameter for the measurements of adhesion potential to soil particles. Appl Environ Microbiol 55, 142-147.

Thamdrup, B. (2000). Bacterial manganese and iron reduction in aquatic sediments. In Advances in Microbial Ecology, vol. 16, pp. 4182. Edited by B. Schink. New York: Kluwer Academic/Plenum.

Turick, C. E., Louis, S. T. \& Caccavo, F., Jr (2002). Melanin production and use as a soluble electron shuttle for $\mathrm{Fe}$ (III) oxide reduction and as a terminal electron acceptor by Shewanella algae BrY. Appl Environ Microbiol 68, 2436-2444.

Vadillo-Rodriguez, V., Busscher, H. J., Norde, W., De Vries, J. \& Van der Mei, H. C. (2004a). Relations between macroscopic and microscopic adhesion of Streptococcus mitis strains to surfaces. Microbiology 150, 1015-1022.
Vadillo-Rodríguez, V., Busscher, H. J., Norde, W., De Vries, J. \& Van der Mei, H. C. (2004b). Dynamic cell surface hydrophobicity of Lactobacillus strains with and without surface layer proteins. J Bacteriol 186, 6647-6650.

Vadillo-Rodríguez, V., Busscher, H. J., Van der Mei, H. C., De Vries, J. \& Norde, W. (2005). Role of lactobacillus cell surface hydrophobicity as probed by AFM in adhesion to surfaces at low and high ionic strength. Colloids Surf B Biointerfaces 41, 33-41.

Van Oss, C. J. (1994). Interfacial Forces in Aqueous Media. New York: Marcel Dekker.

Van Oss, C. J., Good, R. J. \& Chaudhury, M. K. (1986). The role of van der Waals forces and hydrogen bonds in 'hydrophobic interactions' between biopolymers and low energy surfaces. J Colloid Interface Sci 111, 378-390.

Vinogradov, E., Korenevsky, A. \& Beveridge, T. J. (2002). The structure of the carbohydrate backbone of the LPS from Shewanella putrefaciens CN32. Carbohydr Res 337, 1285-1289.

Vinogradov, E., Korenevsky, A. \& Beveridge, T. J. (2003a). The structure of the O-specific polysaccharide chain of the Shewanella algae BrY lipopolysaccharide. Carbohydr Res 338, 385-388.

Vinogradov, E., Korenevsky, A. \& Beveridge, T. J. (2003b). The structure of the rough-type lipopolysaccharide from Shewanella oneidensis MR-1, containing 8-amino-8-deoxy-Kdo and an openchain form of 2-acetamido-2-deoxy-D-galactose. Carbohydr Res 338, 1991-1997.

Vinogradov, E., Korenevsky, A. \& Beveridge, T. J. (2004). The structure of the core region of the lipopolysaccharide from Shewanella algae BrY, containing 8-amino-3,8-dideoxy-D-manno-oct-2-ulusonic acid. Carbohydr Res 339, 737-740.

Vinogradov, E., Nossova, L., Korenevsky, A. \& Beveridge, T. J. (2005). The structure of the capsular polysaccharide of the Shewanella oneidensis MR-4. Carbohydr Res 340, 1750-1753.

Vogler, E. A. (1998). Structure and reactivity of water at biomaterial surfaces. Adv Colloid Interface Sci 74, 69-117.

Williams, V. \& Fletcher, M. (1996). Pseudomonas fluorescens adhesion and transport through porous media are affected by lipopolysaccharide composition. Appl Environ Microbiol 62, 100-104.

Williams, P., Lambert, P. A., Haigh, C. G. \& Brown, M. R. W. (1986). The influence of the $\mathrm{O}$ and $\mathrm{K}$ antigens of Klebsiella aerogenes on surface hydrophobicity and susceptibility to phagocytosis and antimicrobial agents. J Med Microbiol 21, 125-132.

Edited by: C. Picioreanu 